University of Nebraska - Lincoln

DigitalCommons@University of Nebraska - Lincoln

Faculty Publications from the Harold W. Manter Laboratory of Parasitology

$6-2006$

Paracreptotrema blancoi n. gen., n. sp. (Digenea:

Plagiorchiformes: Allocreadiidae) in the Olomina, Priapichthys annectens (Osteichthyes: Poeciliidae), from the Área de Conservación Guanacaste, Costa Rica

Anindo Choudhury

St. Norbert College, anindo.choudhury@snc.edu

Gerardo Pérez Ponce de León

Universidad Nacional Autónoma de México, ppdleon@servidor.unam.mx

Daniel R. Brooks

University of Toronto,dnlbrooks@gmail.com

Rita Daverdin

Norwegian Institute for Nature Research

Follow this and additional works at: https://digitalcommons.unl.edu/parasitologyfacpubs

Part of the Parasitology Commons

Choudhury, Anindo; Pérez Ponce de León, Gerardo; Brooks, Daniel R.; and Daverdin, Rita, "Paracreptotrema blancoi n. gen., n. sp. (Digenea: Plagiorchiformes: Allocreadiidae) in the Olomina, Priapichthys annectens (Osteichthyes: Poeciliidae), from the Área de Conservación Guanacaste, Costa Rica" (2006). Faculty Publications from the Harold W. Manter Laboratory of Parasitology. 286.

https://digitalcommons.unl.edu/parasitologyfacpubs/286

This Article is brought to you for free and open access by the Parasitology, Harold W. Manter Laboratory of at DigitalCommons@University of Nebraska - Lincoln. It has been accepted for inclusion in Faculty Publications from the Harold W. Manter Laboratory of Parasitology by an authorized administrator of DigitalCommons@University of Nebraska - Lincoln. 


\title{
PARACREPTOTREMA BLANCOI N. GEN., N. SP. (DIGENEA: PLAGIORCHIFORMES: ALLOCREADIIDAE) IN THE OLOMINA, PRIAPICHTHYS ANNECTENS (OSTEICHTHYES: POECILIIDAE), FROM THE ÁREA DE CONSERVACIÓN GUANACASTE, COSTA RICA
}

\author{
Anindo Choudhury, Gerardo Pérez-Ponce de León*, Daniel R. Brooks †, and Rita Daverdinł \\ Division of Natural Sciences, St. Norbert College, 100 Grant Street, DePere, Wisconsin 54115. e-mail: anindo.choudhury@snc.edu
}

\begin{abstract}
A new species of allocreadiid digenean is described from Priapichthys annectens (Regan) (Osteichthyes: Poeciliidae) in the Área de Conservación Guanacaste, Costa Rica. A new genus, Paracreptotrema, is proposed to accommodate this species as well as Fellodistomum mendezi Songandares-Bernal, 1955, which was previously described from another poeciliid, Brachyrhaphis episcopi, in Panama. Paracreptotrema differs from all other nominal genera of Allocreadiidae by a combination of its symmetrical testes, restricted vitellaria, and the lack of oral lappets (muscular 'papillae') or other such appendages. Paracreptotrema blancoi $\mathrm{n}$. sp. resembles Creptotrema creptotrema Travassos, Artigas and Pereira, 1928, but differs in lacking ventral oral lappets and in having vitellaria extending posteriorly only to the level of the testes. It can be distinguished from $P$. mendezi n. comb. in having a relatively larger and more posteriorly placed acetabulum, vitellaria that are more restricted anteriorly, smaller testes, and a uterus that does not extend to the posterior end of the body. The genus seems to be restricted to poeciliids in Central America.
\end{abstract}

The parasites of freshwater fishes in Central America remain poorly known. Previous studies include surveys of some fish species in Nicaragua (Watson, 1976; Aguirre-Macedo et al., 2001a, 2001b) and reports of individual parasite species (Sogandares-Bernal, 1955; Caballero and Brenes, 1957; BravoHollis and Arroyo, 1962; Vidal-Martínez et al., 2001; Choudhury et al., 2002; Scholz et al., 2004). Of these, the reports of the digeneans Acanthostomum gnerii Szidat, 1954, 2 Crassicutis spp., and, most recently, Wallinia chavarriae Choudhury, Hartvigsen-Daverdin and Brooks, 2002, seem to be the only records of endohelminths inhabiting freshwater fish from Costa Rica (Caballero and Brenes, 1957; Bravo-Hollis and Arroyo, 1962; Choudhury et al., 2002; Rodríguez-Ortíz, García-Prieto, and Pérez-Ponce de León, 2004, Rodriquez-Ortiz, García-Prieto, Herrera-Vázquez, and Pérez-Ponce de León, 2004). During June, 1998, freshwater fishes from the Área de Conservación Guanacaste (ACG) in northwestern Costa Rica were examined as part of an ongoing biodiversity inventory of the eukaryotic parasites of vertebrates in this area (http://brooksweb.zoo.utoronto.ca). During that study, a hitherto undescribed species of digenean was collected in the poeciliid Priapichthys annectens (Regan), which is described here.

\section{MATERIALS AND METHODS}

Eight $P$. annectens were caught on 28 June 1998, in the Rio Orosí, in the ACG, Guanacaste Province, Costa Rica. Fish were caught by electroshocking, brought to the laboratory at the Centro de Investigación of the ACG's Santa Rosa field station, and examined within 1-4 $\mathrm{hr}$ of capture. Digeneans were collected live, washed briefly in $0.6 \%$ saline, killed by rapid immersion in steaming hot water, followed immediately by fixation in alcohol-formalin-acetic acid, or killed and fixed simultaneously in steaming hot $5 \%$ formalin (VanCleave and Mueller, 1932) accompanied by brief, vigorous shaking. They were stained with acetocarmine, dehydrated, and mounted in balsam on slides or between 2 coverslips. The double coverslip preparations were permanently held

Received 8 June 2005; revised 18 November 2005; accepted 18 November 2005.

* Laboratorio de Helmintología, Departamento de Zoología, Instituto de Biología, UNAM Ap. Postal 70-153, C.P. 04510, México D.F., México.

† Department of Zoology, University of Toronto, Toronto, Ontario M5S 3G5, Canada.

$\ddagger$ Norwegian Institute for Nature Research (NINA), Tungasletta 2, 7485

Trondheim, Norway. in aluminum Cobb slides. Specimens were examined using bright-field and differential interference contrast optics on Olympus BX 50 and BX 51 microscopes. Illustrations were made with a drawing tube attached to the microscope.

The following museum specimens were examined (accession numbers are preceded by the museum abbreviations and the number of specimens examined are in parentheses): $C$. creptotrema: CHIOC $6086(4)$, 6087 (1), 6088 (1), 6089 (19), 32.110b (2), 32.110c (1), 32.110d (1), $32.110 \mathrm{e}$ (2), 32.110f (1), 32.110g (1), 32.110h (1), 32.110i (1); Creptotrematina dissimilis (de Frietas, 1941): CHIOC 10.719a (1), 10.720 (2). Creptotrematina dispar (de Freitas, 1941): CHIOC 15.357 (1); Creptotrema paraensis Vicente, Santos and Souza, 1978: CHIOC 31.205 (holotype); Creptotrema funduli Mueller, 1934: USNPC 32543 (cotypes, numerous specimens); Creptotrematina aguirrepequenoi Jiménez, 1973, ex. Astyanax mexicanus (Filippi) San Marcos River, Texas (loan from Dr. Norman Dronen, Texas A\&M University, College Station, Texas) (1); Fellodistomum mendezi Sogandares-Bernal, 1955, USNPC 37482 (holotype and paratype); Paracreptotrematina limi: ex. Umbra limi (Kirtland), Brokenhead River, Manitoba, Canada, voucher specimens $(>20)$ in AC's collection. USNPC is the U.S. National Parasite Collection, Beltsville, Maryland; HWML is the Harold W. Manter Laboratory of Parasitology, University of Nebraska, Lincoln, Nebraska; CHIOC refers to Coleção Helmintológica, Instituto Oswaldo Cruz, Rio de Janeiro, Brazil; and CNHE is the Colección Nacional de Helmintos, Instituto de Biología, Universidad Nacional Autónoma de México, Mexico City. Measurements are given in micrometers $(\mu \mathrm{m})$ and are expressed as mean \pm standard deviation followed by the range in parentheses. Measurements are from 20 specimens unless otherwise mentioned.

\section{DESCRIPTION}

\section{Paracreptotrema n. gen.}

Diagnosis: Body aspinose, slightly flattened, widest in mid region, with bluntly rounded ends. Oral lappets or lobes lacking. Oral sucker smaller than acetabulum. Pharynx well developed. No discernible prepharynx. Esophagus short. Ceca reaching testes, overlapping anterior region of testes. Testes symmetrical, entire. Cirrus sac elongate, containing folded seminal vesicle, pars prostatica, short ejaculatory duct. Ovary sinistral or dextral, posterolateral to acetabulum, entire. Seminal receptacle postovarian. Laurers canal present. Vitellaria extending along and overlapping ceca ventrally, from level of esophagus to level of testes. Uterus looping between testes, loop extending posterior to testes or not, but not filling posttesticular region. Eggs few, large, operculate. Excretory bladder I-shaped, extending to level of testes.

\section{Taxonomic summary}

Type species: $P$. blancoi.

Other species: P. mendezi (Sogandares-Bernal, 1955) n. comb. (Syn. Fellodistomum mendezi Sogandares-Bernal, 1955). 
Etymology: The genus is named after the fact that it resembles Creptotrema Travassos, Artigas and Pereira, 1928 and may be closely related to it.

\section{Remarks}

The assigning of genera to Allocreadiidae remains somewhat subjective, especially in the absence of life cycle data (Gibson, 1996; Caira and Bogéa, 2005), but we place Paracreptotrema in Allocreadiidae because it possesses all the adult characteristics of the family described by Caira and Bogéa (2005). These characteristics include, most notably, the aspinose tegument, the unarmed cirrus, well developed cirrus sac, the absence of an external seminal vesicle, the tubular excretory vesicle restricted to the hindbody, and the general disposition of the vitellaria and gonads. Paracreptotrema also resembles the allocreadiid genus Creptotrema closely in having a similar size and fusiform shape, a conspicuous acetabulum, similarly placed gonads, mainly lateral vitellaria, and few large eggs. The most recent revision of Allocreadiidae (Caira and Bogéa, 2005) recognizes 15 genera. To this list can be added Auriculostoma Scholz, Agueirre-Macedo and Choudhury, 2004 (Scholz et al. 2004). Paracreptotrema can be readily distinguished from 10 of these 16 genera of Allocreadiidae, viz., Creptotrema Travassos, Artigas and Pereira, 1928; Creptotrematina Yamaguti, 1954; Paracreptotrematina Amin and Myer, 1982; Bunoderella Schell, 1964; Trematichthys Vaz, 1932; Crepidostomum Braun, 1900; Bunoderina Miller, 1936; Allobunodera Yamaguti, 1971; Bunodera Railliet, 1896; and Auriculostoma by the absence of oral lappets ('muscular papillae') or lobes (Caira and Bogéa, 2005). It differs from the other 6 allocreadiid genera listed by Caira and Bogéa (2005) (Margotrema Lamothe-Argumedo, 1970; Culaeatrema Lasee, Font and Sutherland, 1988; Caudouterina Martin, 1966; Polylekithum Arnold, 1934; Pseudoallocreadium Yamaguti, 1971; and Allocreadium Looss, 1900) by a combination of symmetrical testes and more restricted vitellaria.

\section{Paracreptorema blancoi n. sp.} (Figs. 1-4)

Description: Body $688 \pm 95$ (500-850) long. Anterior end rounded; body widening gradually, reaching maximum width of $349 \pm 47.6$ $(250-450)$ at level of acetabulum, terminating in narrower posterior end. Oral sucker $126.7 \pm 15.8(100-155)$ long, $126.2 \pm 13.7$ (100155 ) wide, with 2 papillae on posterior margin (not visible on all specimens), several papillae along outer edge; opening subterminal, anteroventrally directed. Ventral oral lappets or lobes lacking. Acetabulum $153.2 \pm 15.3$ (120-175) long, $174 \pm 21.4$ (130-205) wide, strongly muscular, sunken, visible externally by its rounded opening; tegument of acetabulum with fine striations radiating outward from acetabular opening. Oral sucker length: acetabulum length 1:1.2 (1.2-1.21) and oral sucker width: acetabulum width 1:1.4 (1.2-1.7). Prepharynx absent. Pharynx muscular, well developed, $50 \pm 6.3(40-60)$ long, $57 \pm 7.7$ (45-75) wide. Esophagus short, winding, $27.5 \pm 9.7$ (15-45). Cecal bifurcation short distance anterior to acetabular margin. Ceca extending posterior to acetabulum, terminating blindly at level of anterior region of testes, $204 \pm 15.5(140-280)$ from posterior end. Ovary $86.2 \pm 17.3$ (55-110) long, $69.2 \pm 15.9$ (35-62.5) wide, rounded, entire, dextral or sinistral, immediately postacetabular, overlapping with anterior border of testis. Mehlis' gland comprised of loose aggregate of gland cells. Seminal receptacle postovarian, muscular. Laurer's canal long, extending laterally, opening dorsal to lateral edge of testis. Uterus short, mostly pretesticular with short loop extending between testes, metraterm weakly developed. Eggs few, well developed, ovoid, operculate, 55.4 $\pm 2.3(52.5-62.5)$ long $(n=18), 38.5 \pm 2.3(32.5-42.5)$ wide $(n=$ 18). Vitellaria follicular, in 2 ventrolateral fields, extending from level of pharynx or esophagus to anterior margin of testes, follicles overlapping cecal field ventrally, row of follicles occasionally present along inner margin of ceca, follicles consisting of granular vitelline cells; vitelline ducts emptying into conspicuous median vitelline reservoir filled with vitellocalcyl cells. Testes 2 , symmetrical, rounded or ellipsoidal, entire, left testis $132 \pm 24.6$ (90-170) long, $94.7 \pm 15.8$ (70-120) wide, posterior margin $134.2 \pm 27.8(95-190)$ from posterior end of body; right testis $134 \pm 20.2(89-167)$ long $\pm 95.1 \pm 18$ (74-115) wide, posterior margin $133.7 \pm 26.8$ (85-185) from posterior end of body. Cirrus sac elongate, median, dorsal, maximum width $52 \pm 7.7$ (3562.5) $(n=18)$, containing folded tubular seminal vesicle, conspicuous ovoid glandular pars prostatica, curved unarmed ejaculatory duct; posterior end of cirrus sac $57.1 \pm 20.53(12.5-102.5, \mathrm{n}=18)$ anterior to posterior margin of acetabulum. Genital pore median, at or immediately posterior to cecal bifurcation. Excretory vesicle I-shaped, tubular, narrow, reaching anteriorly to slightly beyond level of posterior margin of testes. Excretory pore terminal.

\section{Taxonomic summary}

Type host: Priapichthys annectens (Regan, 1907) (Osteichthyes: Poeciliidae).

Site of infection: Intestine.

Prevalence of infection: Seven of 8 infected (87.5\%). 3-10 worms per fish. Mean abundance: $7.43 \pm 3.1$.

Type locality: Río Orosí, ACG, Guanacaste Province, Costa Rica. Universal Transverse Mercator (UTM) Coordinates: 3804 3300. Locality is $\sim 675 \mathrm{~m}$ above sea level.

Specimen deposition: Holotype: USNPC 97785. Paratypes, CNHE 5315 (3 specimens); USNPC $97786-97789$ (10 specimens).

Etymology: The species is named in honor of Roger Blanco, Associate Director for Research at the ACG, for his untiring efforts in ensuring that the ACG remains one of Costa Rica's premier biodiversity conservation areas and a vital natural laboratory.

\section{Remarks}

The generic name reflects the resemblance of $P$. blancoi to $C$. creptotrema, from which it differs in lacking ventral oral lappets and in possessing vitellaria extending posteriorly only to the level of the testes. Paracreptotrema blancoi closely resembles $F$. mendezi, which was described "based chiefly on a single favorable specimen" (SogandaresBernal, 1955), in Brachyrhaphis episcopi, also a poeciliid, from Gatun Lake, Panama. The morphology of both species differs in some notable ways from the diagnosis of Fellodistomum Stafford 1904, and of Fellodistomidae Nicoll 1909. As part of the diagnosis for the family Fellodistomidae, Bray (2002) mentions a Y- or V-shaped excretory vesicle "with anterior arms reaching about the level of pharynx" and a uterus with numerous small eggs. Neither is true for Paracreptotrema, which has a tubular excretory bladder reaching to the level of the testes and a uterus with few large eggs. Sogandares-Bernal (1955) described the excretory bladder of $F$. mendezi as Y-shaped. Examination of the holotype and paratype of $F$. mendezi failed to confirm this shape; the holotype seems to have a tubular excretory bladder. Diagnostic characters of Fellodistomum include a bipartite seminal vesicle, wide pars prostatica, sinistrally submedian genital pore, and a multilobate ovary. None of these features is present in $P$. blancoi or $F$. mendezi. Furthermore, species of Fellodistomum are parasitic in the bile duct and gall bladder of marine teleosts (Yamaguti, 1971; Bray, 2002). On the basis of this knowledge and the resemblance of Paracreptotrema to Creptotrema, we contend that neither $P$. blancoi nor $F$. mendezi belong in Fellodistomidae. As a result, we transfer $F$. mendezi to Paracreptotre$m a$, and it becomes $P$. mendezi $\mathrm{n}$. comb. Paracreptotrema blancoi can be distinguished from $P$. mendezi in having a relatively larger and more posteriorly placed acetabulum, vitellaria that do not overlap the pharynx, a rounded ovary as opposed to a subtriangular ovary, smaller testes, and a uterus that does not extend to the posterior end of the body.

\section{DISCUSSION}

We tentatively assign Paracreptotrema to Allocreadiidae, where it joins Creptotrema and a diverse collection of aspinose plagiorchiiforms (Caira and Bogéa, 2005; see Remarks section for Paracreptotrema). In the absence of a phylogenetic analysis that includes all allocreadiids, it is not possible at present to judge whether the absence of lappets and the restriction of the vitellaria are derived states for Paracreptotrema, implying that it may be a more recently evolved clade closely related to Creptotrema, or whether 1 or both of these character states are plesiomorphic. This situation is reminiscent of Culaeatrema inconstans Lasee, Font and Sutherland, 1988, originally described by Lasee et al. (1988) to represent a monotypic genus and later 
FIGURES 1-4. P. blancoi. (1) Ventral view (some selected oocytes and cells of the testes illustrated, 1 egg overlying the seminal receptacle omitted). Bar $=100 \mu \mathrm{m}$. (2) Anterior end showing tegumental papillae. Bar $=100 \mu \mathrm{m}$. (3) Cirrus sac (curved ejaculatory duct mainly in en face view). Bar $=50 \mu \mathrm{m}$. (4) Female reproductive complex (e, egg in proximal uterus). Bar $=50 \mu \mathrm{m}$. 
shown to be a species of Bunodera that had lost its muscular oral lappets over evolutionary time (Brooks, 1992). Caira and Bogéa (2005) chose to recognize Culaeatrema Lasee, Font and Sutherland, 1988, until a more extensive analysis of the Allocreadiidae is available.

Paracreptotrema blancoi and $P$. mendezi are both parasites of poeciliid fishes, and, at present, the genus is known only from Central America. It is possible that such parasites will be found in these and other poeciliids elsewhere in the Neotropical region. Within the ACG, $P$. blancoi seems to be an exclusive parasite of $P$. annectens in Río Orosí, which is an Atlantic drainage. None of the other 369 individuals, belonging to 21 species of fishes, examined in the ACG during this phase of the work (June 1998, Choudhury et al., 2002; data not shown) was infected with this species. In addition, none of the 47 individuals of this poeciliid that were examined in other rivers of the Atlantic drainage portion of the ACG during June 1998 and March 2001 was found infected with $P$. blancoi.

\section{ACKNOWLEDGMENTS}

We acknowledge the following people, whose untiring help and support ensured a successful 1998 field season: our collaborator and the principal investigator of fish biodiversity studies in the ACG, Odd Terje Sandlund, Norwegian Institute for Nature Research (NINA), Trondheim, Norway; Mark Daverdin for help with collections, necropsy work, and data entry; and the scientific and technical staff at the ACG, particularly Maria Marta Chavarría Díaz, Roger Blanco, Alejandro Masis, Guillermo Jiménez, Duñia García, Elda Arraya, Carolina Cano, Calixto Moraga, Fredy Quesada, Roberto Espinosa, Elba Lopez, and Petrona Rios. Duñia, Elda, Carolina, Calixto, Fredy, Roberto, Elba, and Petrona helped with the necropsy work. We also thank the following individuals for the loan of specimens: Patricia Pilitt and Eric Hoberg, U.S. National Parasite Collection, Beltsville, Maryland; Luis Cláudio Muñiz Pereira, Fundação Instituto Oswaldo Cruz, Rio de Janeiro, Brazil; and Norman Dronen, Texas A\&M University, College Station, Texas. This study is part of a biodiversity inventory of parasites of the 970 vertebrate species in the ACG, in northwestern Costa Rica. A.C. acknowledges a Natural Sciences and Engineering Research Council (NSERC) postdoctoral fellowship with D.R.B. at the University of Toronto. This study was supported by an NSERC operating grant to D.R.B.

\section{LITERATURE CITED}

AgUiRRE-MACEdo, M. L., T. SChOlZ, D. GonZÁlez-SOLís, V. M. VidALMartínez, P. Posel, G. Arjona-Torres, E. Siu Estrada, and S. DUMAILO. 2001a. Larval helminths parasitizing freshwater fishes from the Atlantic Coast of Nicaragua. Comparative Parasitology 68: $42-51$.

$2001 \mathrm{~b}$. Some adult helminths parasitizing freshwater fishes from the Atlantic coastal drainages of Nicaragua. Comparative Parasitology 68: 190-195.
Bravo-Hollis, M., AND G. Arroyo. 1962. Tremátodos de peces de Costa Rica. I. Sobre dos especies del género Crassicutis Manter, 1936 (Lepocreadiidae Nicoll, 1914) del intestino de Cichlasoma. Revista de Biología Tropical 10: 229-235.

BrAY, R. A. 2002. Family Fellodistomidae Nicoll, 1909. In Keys to the Trematoda. Vol. 1. D. I. Gibson, and R. A. Bray (eds.). CAB International and The Natural History Museum, Wallingford, U.K., p. 261-293.

BROOKS, D. R. 1992. New distributional records for Bunodera eucaliae and Bunodera inconstans n. comb. (Digenea: Allocreadiidae: Bunoderinae) with discussion of their phylogenetic relationships. Journal of Parasitology 78: 779-783.

Caballero, C. E., AND M. R. Brenes. 1957. Helmintos de la Republica de Costa Rica VI. Algunos tremátodos de peces, reptiles y mamíferos. Anales del Instituto Biología, México 28: 217-240.

CAIRA, J. N., AND T. BoGÉA. 2005. Family Allocreadiidae Looss, 1902. In Keys to the Trematoda. Vol. 2. A. Jones, R. A. Bray, and D. I. Gibson (eds.). CAB International, Wallingford, U.K., pp. 417-436.

Choudhury, A., R. Hartvigsen Daverdin, AND D. R. BROOKS. 2002. Wallinia chavarriae n. sp. (Trematoda: Macroderoididae) in Astyanax aenaeus (Günther, 1860) and Bryconamericus scleroparius (Regan, 1908) (Osteichthyes: Characidae) from the Area de Conservación Guanacaste, Costa Rica. Journal of Parasitology 88: 107112.

Gibson, D. I. 1996. Trematoda. In Guide to the parasites of fishes of Canada. Part IV. Canadian Special Publication of Fisheries and Aquatic Sciences 124: 1-373.

LASEe, B. A., W. F. Font, AND D. R. Sutherland. 1988. Culaeatrema inconstans gen. n., sp. n. (Digenea: Allocreadiidae) in Wisconsin and observations on parthenogenetic populations. Canadian Journal of Zoology 66: 1328-1333.

Rodríguez-Ortiz, B., L. García-Prieto, and G. PÉrez-Ponce de León. 2004. Checklist of the helminth parasites of vertebrates in Costa Rica. Revista de Biología Tropical 52: 1-41.

- , J. Herrera-VÁsquez, and G. Pérez-Ponce de León. 2004. Addendum to the Checklist of the helminth parasites of vertebrates in Costa Rica. Revista de Biología Tropical 52: 41-48.

Scholz, T., L. Aguirre-Macedo, AND A. Choudhury. 2004. Auriculostoma astyanace n. gen., n. sp. (Digenea: Allocreadiidae), from the banded astyanax, Astyanax fasciatus (Characiformes: Characidae), from Nicaragua, with a reevaluation of Neotropical Crepidostomum spp. Journal of Parasitology 90: 1128-1132.

Sogandares-BERNAL, F. 1955. Some helminth parasites of fresh and brackish water fishes from Louisiana and Panama. Journal of Parasitology 41: 587-594.

VanCleave, H. J., AND J. F. Mueller. 1932. Parasites of Oneida Lake fishes. Part III. A bioogical and ecological survey of the worm parasites. Roosevelt Wildlife Annals 3: 161-334.

Vidal-Martínez, V., T. Scholz, and M. L. Aguirre-Macedo. 2001. Dactylogyridae of cichlid fishes from Nicaragua, Central America, with descriptions of Gussevia herotilapiae sp. $\mathrm{n}$. and three species of Sciadicleithrium (Monogenea: Ancyrocephalinae). Comparative Parasitology 68: 76-86.

WATSON, D. E. 1976. Digenea of fishes from Lake Nicaragua. In Investigations of the ichthyofauna of Nicaraguan lakes, T. B. Thorson (ed.). University of Nebraska, Lincoln, Nebraska, p. 251-260.

YAMAGUTI, S. 1971. Synopsis of digenetic trematodes of vertebrates. Vols. 1 \& 2. Keigaku Publishing Co., Tokyo, Japan, 1074 p. 